\title{
POLITICAL PARTY MEMBERSHIP AND PERSONALITY CHARACTERISTICS IN THE CZECH REPUBLIC (2005)
}

\author{
Václav Linkov
}

\begin{abstract}
This paper examines the relationship between Big Five personality dimensions and membership in political parties in the Czech Republic. A total of 194 members from eight major Czech political parties filled out the NEO Five-Factor Inventory to assess the Big Five personality dimensions. The mean scores of the respondents from each party were compared to the scores of a sample of the general Czech population. The members of three right-wing parties scored lower in agreeableness and the members of one left-wing party were higher in agreeableness than the general population, which is consistent with results from other countries. The Greens scored higher in openness than the general population, which is consistent with results from Germany. Members of former governing parties, which had long been out of power, scored lower in neuroticism than the general population.
\end{abstract}

Keywords: five-factor model, political preferences, Czech political parties

\section{Acknowledgements}

This article was produced with the financial support of the Ministry of Education, Youth and Sports within the National Sustainability Programme I, project of Transport R\&D Centre (LO1610), on the research infrastructure acquired from the Operation Programme Research and Development for Innovations (CZ.1.05/2.1.00/03.0064). I thank Martina Hřebíčková for giving me information about NEO-FFI scales. I also thank Stanislav Ježek, Vladimír Smékal, Lubomír Kostroň, and Dominika Klenová for their advice concerning this research. I thank all the people who helped me with collecting subjects.

Received: 15. 11. 2019

Approved: 14. 7. 2020

Published online: 5. 8. 2020 


\section{Introduction}

The relationship between personality and political orientation is a theme that has always been interesting for psychologists. Most of the texts published on this topic are about political orientation and voter decision-making; active politicians are only seldom considered. Italy has done some research based on samples of politicians (Caprara, Barbarenelli, Consiglio, Picconi \& Zimbardo, 2003), so has Belgium (Joly, Hofmans \& Loewen, 2018). Yet, there is a lack of published research on the relevant parties within the large multi-party transitioning political systems of former communist countries. I collected responses from the members of eight relevant parties in the Czech multi-party system in 2005 and asked them to complete a questionnaire to measure the five factors of personality (Costa \& McCrae, 1999). (The samples include members of three parties which have since dissolved.) This paper aims to fill the gap in the published research concerning multi-party systems in post-communist countries at the time of their transition to democracy. Below, I describe the Czech political party system in 2005. Then I review the relevant published research about the relationship between political preferences and the Big Five personality traits. Finally, based on the collected data, I address the differences between the Big Five personality dimensions of the consenting party-members in the Czech Republic and the general population.

\section{Czech political parties in 2005}

Many political parties were established after the fall of the communist regime in Czechoslovakia in 1989. Some of these parties existed for only a few years; some were successful into the early 90s, and; some remain successful today. The system of political parties in the Czech Republic had been stable from 1998 to 2005 when I collected data from the respondents. Two parties alternated as the most powerful: The Civic Democratic Party (Občanská demokratická strana, ODS) and the Czech Social Democratic Party (Česká strana sociálně demokratická, ČSSD). ODS was established in 1991 as a conservative political party with some liberal accents. ČSSD is a traditional European social democratic party. The third most powerful political party was the Communist Party of Bohemia and Moravia (Komunistická strana Čech a Moravy, KSČM; see Handl, 2005). This party is the successor of the Communist Party of Czechoslovakia, which held power during the communist era of 19481989. There was only one additional party that had stable voters from the early 1990s to 2005 - the Christian and Democratic Union - Czechoslovak People's Party (Křest'anská a demokratická unie - Československá strana lidová, KDU-ČSL). KDU-ČSL was at the center of the Czech political spectrum and it joined coalitions with both major parties from 1992 to 2010 .

Other parties examined in this paper were not stable parties on the Czech political scene. The Civic Democratic Alliance (Občanská demokratická aliance, ODA) and the European Democrats (Evropští demokraté, ED) were small right-wing parties. ODA was a liberalconservative party established in 1989. It was rather influential in 1992-1998 but lost many of its voters in 1998 and dissolved in 2009. ED was established in 2002 by a break-away group of former ODS members. It met the required 5\% threshold and entered the European Parliament in 2004 (Hanley, 2012). The Green Party (Strana zelených, SZ; Cordell \& Hausvater, 2006) reached its peak in 2006 when it exceeded the threshold for the Czech Parliament. The Moravian Democratic Party (Moravská demokratická strana, MDS) was a small party established in 1997 in a merger of even smaller parties. It participated only in the politics of the Moravian region. MDS lobbied for the autonomy of Moravia within the Czech political system 
and its leaders spoke about discrimination against Moravians by the Czech governmental authorities. It was renamed Moravané (Moravians) in 2005 after I had finished collecting respondents (Hloušek, 2015) and later lost significance.

\section{Political preferences and personality}

The literature on the relationship between personality and political orientation is rich because the matter has been examined in many countries. For example, center-right voters in Italy were found to be higher in extraversion and conscientiousness but lower in openness to experience and agreeableness than center-left voters (Caprara, Barbaranelli, \& Zimbardo, 1999). The same results were obtained for the voters in the Italian elections in 2001 (Caprara, Schwartz, Capanna, Vecchione, \& Barbaranelli, 2006). Caprara et al. (2003) showed that center-right Italian politicians were higher in extraversion and conscientiousness than center-left politicians. In Canada, politicians' extraversion was correlated with left orientation (Joly, Hofmans \& Loewen, 2018). In a Belgian sample, conscientiousness (positively) and agreeableness (negatively) were correlated with a center-right preference (Van Hiel et al., 2004). The negative correlation of openness with the preference for rightist parties was identified in many other samples as well. Americans who prefer liberalism over conservatism are more open and extraverted and less neurotic and conscientious (Cooper, Golden, \& Socha, 2013; Xu \& Peterson, 2017; Ekstrom \& Federico, 2019; Ludeke \& Rasmussen, 2016). Wang (2016) found a connection between liberal preferences and neuroticism in the United States. Openness, agreeableness, extraversion, and lower conscientiousness were found to be related to the leftwing orientation in a British sample (Furnham \& Fenton-O'Creavy, 2018). Osborne and Sibley (2012) found that a conservative (as opposed to liberal) vote in both New Zealand and the United States is related to higher conscientiousness and lower neuroticism, lower agreeableness, and lower openness to experience. Liberal political orientation is correlated with openness, agreeableness, and lower conscientiousness in Australia (Devenport \& North, 2019). Openness to experience was negatively correlated with right-wing preference in the samples of the Belgian population (Van Hiel et al., 2004) and politicians (Joly, Hofmans, \& Loewen, 2018). Right-wing Authoritarianism (RWA) is also negatively correlated with openness (Duckitt \& Sibley, 2016).

Schoen and Schumann (2007) conducted research into the relationship between voting preference and personality in Germany. Openness to experience was related to a voting preference for the Green Party and SPD, and low openness was related to a voting preference for CDU/CSU and extreme right parties. A high level of conscientiousness was related to a preference for CDU/CSU and a low level of conscientiousness was related to a preference for the Greens. High agreeableness was connected to a preference for SPD and the Greens, and low agreeableness was connected to voting for CDU/CSU and extreme right parties. High neuroticism corresponded to the preference for extreme right parties and low neuroticism corresponded to the preference for FDP.

In the UK, preference for the Conservatives is related to higher extraversion and conscientiousness and lower neuroticism, openness, and agreeableness. Preference for the Labour Party is related to higher agreeableness, openness, extraversion, and neuroticism, and lower conscientiousness. Preference for the Liberal Democrats is related to higher openness and neuroticism and lower conscientiousness and extraversion (Aidt \& Rauh, 2018). 
In the Czech Republic, the relationship between left-wing preference and openness could be influenced by one specific factor: as a result of 40 years of the communist regime, the Czech left-wing voters highly value tradition (Hnilica, 2001), which is consistent with authoritarian values present among communists during the Cold War era (McFarland, Ageyev, \& AbalakinaPaap, 1992). Yet, tradition is regarded highly by right-wing voters in many other countries (Caprara et al., 2006).

This research mainly concerns parties classified in the dichotomy of left/right or liberal/conservative. Such findings are hard to use when making hypotheses about the relationships between personality and political preference in a multi-party system, like the one in the Czech Republic. Based on the international findings, it could be expected that left-wing party members (i.e., ČSSD, KSČM) would score higher in openness and agreeableness, and less on conscientiousness than the general population (although, it should be mentioned that this is a former totalitarian party, so it is questionable whether it should be considered similar to Western left-wing parties). The opposite could be hypothesized about right-wing party members (i.e., ODS, ODA, ED). The Greens might score more in openness and agreeableness and less in conscientiousness than the sample of the general population. The hypotheses above are derived from international findings, it should be stressed though that the Communist Party, in particular, has a very different position in the Czech Republic than the Communists do in the West. As soon as the Communist Party of Czechoslovakia gained power in 1948, it changed the democratic regime into totalitarianism; Czechoslovakia became democratic again only after a peaceful velvet revolution in 1989. Thus, the Communists who stayed loyal to their party even after it lost its power are psychologically very different from their Western counterparts, if nothing else, we might expect lower openness in them.

\section{Methods}

\section{Sample}

The respondents were obtained in two ways: I either personally participated in a party meeting or I asked a party member to collect research data. The data collection took place in Brno and Prague, Czech Republic, in 2005. The anonymity of the respondents was fully maintained. I asked each respondent to only provide their age, gender, and how long they had been a member of their party. I tried to get as many respondents as possible. Nevertheless, sample sizes were limited by the small membership of half of the included parties and the unwillingness of some respondents to cooperate. I obtained a total of 194 respondents (see Table 1). 
Table 1. Samples collected and their characteristics

\begin{tabular}{|c|c|c|c|c|c|c|c|}
\hline Party & $\begin{array}{l}\text { Method } \\
\text { of } \\
\text { obtaining } \\
\text { members }\end{array}$ & $\mathrm{N}$ & Men & Women & $\begin{array}{l}\text { Mean } \\
\text { age }\end{array}$ & $\begin{array}{l}\text { Mean time } \\
\text { of } \\
\text { membership } \\
\text { (in years) }\end{array}$ & Location \\
\hline ČSSD & $\begin{array}{l}\text { Party } \\
\text { meeting }\end{array}$ & $43^{*}$ & 27 & 15 & 43 & 10 & Brno \\
\hline SZ & $\begin{array}{l}\text { Party } \\
\text { meeting }\end{array}$ & 24 & 14 & 10 & 36 & 3 & Brno \\
\hline ODS & $\begin{array}{l}\text { Party } \\
\text { meeting }\end{array}$ & 35 & 20 & 15 & 40 & 6 & Brno \\
\hline $\begin{array}{l}\text { KDU- } \\
\text { ČSL }\end{array}$ & Member & 18 & 13 & 5 & 45 & 13 & Brno \\
\hline KSČM & Member & 15 & 12 & 2 & 64 & 32 & Brno \\
\hline ODA & $\begin{array}{l}\text { Party } \\
\text { meeting }\end{array}$ & 31 & 18 & 12 & 52 & 11 & $\begin{array}{l}\text { Czech } \\
\text { Republic }\end{array}$ \\
\hline ED & Member & 17 & 14 & 2 & 37 & 2 & $\begin{array}{l}\text { Czech } \\
\text { Republic }\end{array}$ \\
\hline MDS & Member & 11 & 11 & 0 & 47 & 10 & Moravia \\
\hline
\end{tabular}

* Differences between the number of men and women and the total number of participants are caused by missing data.

Data were collected in two ways. When possible, I attended a party meeting to collect data. Usually, I was not allowed to sit in the hall where the meeting was held, so I waited in the lobby and asked members as they left the hall for coffee or the toilet. In this way, I collected data from ODS, ODA, the Greens, and ČSSD. For small parties (i.e., ODA, Greens), nearly all of the members who attended the meeting agreed to fill in the questionnaire. In the other two parties, the questionnaire was filled in by about one half of the members who attended the meeting. Concerning the data from the other four parties, the party was too small to organize meetings (MDS); I didn't have the opportunity to attend a meeting (ED); I was told to leave when I arrived at the meeting (KSČM); or the party member whom I asked for permission immediately offered me to collect the data himself (KDU-ČSL). In these cases, the data were collected by a member of the party, who offered to help with collection. I do not have information how many party members were contacted by these collaborators and how many refused to fill in the questionnaire.

\section{Measure}

NEO Five-Factor Inventory (NEO-FFI; Hřebíčková \& Urbánek, 2001) is the Czech version of the Big Five personality traits inventory (Costa \& McCrae, 1992). It has 60 items altogether, 12 items for each scale. Cronbach alphas for the samples were 0.74 for neuroticism, 0.82 for extraversion, 0.58 for openness, 0.55 for agreeableness, and 0.84 for conscientiousness. 


\section{Procedure}

Party members filled out the NEO-FFI questionnaire. I received the means and standard deviations of the Czech population sample for NEO-FFI scales from Martina Hřebíčková, one of the authors of the Czech version of the NEO-FFI (see Table 2), so I was able to compare the general population sample scores to the scores of different parties' members.

Data for political parties' members were compared to those of the Czech population sample ( $\mathrm{N}=1165)$, which were fairly recent. Population sample means were 21.8 (SD = 8.8, 95\% CI 21.29 - 22.31) for neuroticism; $29.9(\mathrm{SD}=8.0,95 \%$ CI $29.40-30.32)$ for extraversion; 29.8 $(\mathrm{SD}=6.8,95 \% \mathrm{CI} 29.40-30.18)$ for openness to experience; $30.6(\mathrm{SD}=5.9,95 \% \mathrm{CI} 30.24-$ 30.92) for agreeableness; and 30.9 (SD $=7.8,95 \%$ CI $30.44-31.33$ ) for conscientiousness. I tested the significance of the difference (at the 0.05 level) between the sample of each party and the population sample in each NEO-FFI scale using a t-test for independent samples.

\section{Results}

The differences between party samples and the population sample are shown in Table 2. Social Democrats ( $\breve{C S S D})$ were higher in extraversion $(\mathrm{t}=3.488, \mathrm{p}<0.05)$ and conscientiousness $(\mathrm{t}=3.486, \mathrm{p}<0.05)$ than the Czech population sample, and the Greens (SZ) were higher in openness to experience $(\mathrm{t}=2.820, \mathrm{p}<0.05)$. The members of ODS were lower in openness $(\mathrm{t}=2.019, \mathrm{p}<0.05)$ and agreeableness $(\mathrm{t}=2.578, \mathrm{p}<0.05)$ than the Czech population sample, and the Communists (KSČM) were lower in neuroticism $(\mathrm{t}=2.558, \mathrm{p}<0.05)$ and higher in agreeableness $(\mathrm{t}=2.849, \mathrm{p}<0.05)$. The members of ODA scored lower in neuroticism $(\mathrm{t}=4.330$, $\mathrm{p}<0.05)$ and agreeableness $(\mathrm{t}=2.154, \mathrm{p}<0.05)$, and higher in extraversion $(\mathrm{t}=2.188, \mathrm{p}<0.05)$. ED members scored higher in extraversion $(\mathrm{t}=6.400, \mathrm{p}<0.05)$ and MDS members were lower in agreeableness $(\mathrm{t}=2.222, \mathrm{p}<0.05)$. 
Table 2. Differences between party samples and the Czech population sample

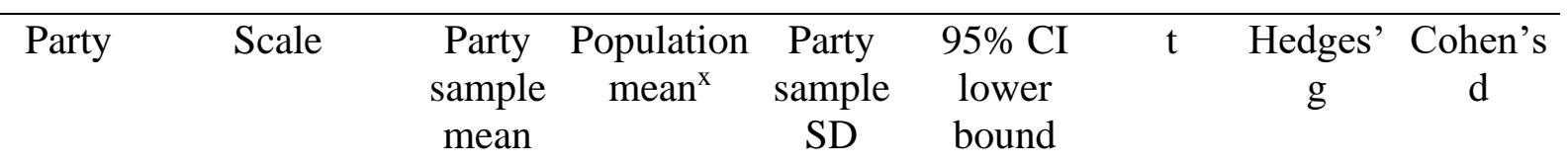

\begin{tabular}{|c|c|c|c|c|c|c|c|c|}
\hline \multirow[t]{5}{*}{ ČSSD } & Neuroticism & 19.28 & 21.78 & 7.31 & $17.04-21.52$ & 1.84 & 0.29 & 0.31 \\
\hline & Extraversion & 34.16 & 29.86 & 7.50 & $31.80-36.52$ & $3.49 *$ & 0.53 & 0.55 \\
\hline & Openness & 28.72 & 29.79 & 5.79 & $26.94-30.50$ & 1.01 & 0.16 & 0.17 \\
\hline & Agreeableness & 28.98 & 30.58 & 5.46 & $27.30-30.66$ & 1.76 & 0.28 & 0.29 \\
\hline & Conscientiousness & 34.16 & 30.89 & 5.96 & $32.32-36.00$ & $3.49^{*}$ & 0.42 & 0.47 \\
\hline \multirow[t]{5}{*}{ SZ } & Neuroticism & 20.88 & 21.78 & 6.79 & $18.00-23.76$ & 0.50 & 0.10 & 0.12 \\
\hline & Extraversion & 30.58 & 29.86 & 9.70 & $26.48-34.68$ & 0.44 & 0.08 & 0.08 \\
\hline & Openness & 32.42 & 29.79 & 4.46 & $30.54-34.30$ & $2.82 *$ & 0.39 & 0.46 \\
\hline & Agreeableness & 30.58 & 30.58 & 4.67 & $28.61-32.55$ & 0.00 & 0.00 & 0.00 \\
\hline & Conscientiousness & 28.21 & 30.89 & 8.19 & $24.75-31.67$ & 1.66 & 0.34 & 0.34 \\
\hline \multirow{5}{*}{ ODS } & Neuroticism & 20.63 & 21.78 & 5.10 & $18.87-22.39$ & 1.28 & 0.11 & 0.13 \\
\hline & Extraversion & 31.69 & 29.86 & 5.47 & $29.81-33.57$ & 1.92 & 0.23 & 0.26 \\
\hline & Openness & 28.03 & 29.79 & 5.02 & $26.29-29.77$ & $2.02 *$ & 0.26 & 0.30 \\
\hline & Agreeableness & 28.71 & 30.58 & 4.17 & $27.28-30.14$ & $2.58^{*}$ & 0.32 & 0.37 \\
\hline & Conscientiousness & 33.40 & 30.89 & 7.08 & $30.95-35.85$ & 1.87 & 0.32 & 0.34 \\
\hline KDU- & Neuroticism & 22.94 & 21.78 & 5.43 & $20.24-25.64$ & 0.89 & 0.13 & 0.16 \\
\hline \multirow{4}{*}{ ČSL } & Extraversion & 31.50 & 29.86 & 6.26 & $28.38-34.62$ & 0.87 & 0.20 & 0.22 \\
\hline & Openness & 29.50 & 29.79 & 5.18 & 26.93-32.07 & 0.18 & 0.04 & 0.05 \\
\hline & Agreeableness & 29.22 & 30.58 & 3.47 & 27.49-30.95 & 1.63 & 0.24 & 0.29 \\
\hline & Conscientiousness & 31.33 & 30.89 & 6.45 & $28.12-34.54$ & 0.24 & 0.06 & 0.06 \\
\hline \multirow[t]{5}{*}{ KSČM } & Neuroticism & 18.47 & 21.78 & 4.91 & $15.75-21.19$ & $2.56^{*}$ & 0.38 & 0.47 \\
\hline & Extraversion & 31.20 & 29.86 & 7.86 & $26.85-35.55$ & 0.65 & 0.16 & 0.16 \\
\hline & Openness & 29.53 & 29.79 & 6.59 & $25.88-33.18$ & 0.15 & 0.04 & 0.04 \\
\hline & Agreeableness & 33.40 & 30.58 & 3.78 & $31.32-35.48$ & $2.85^{*}$ & 0.48 & 0.57 \\
\hline & Conscientiousness & 32.33 & 30.89 & 7.24 & 28.32-36.34 & 1.70 & 0.18 & 0.19 \\
\hline \multirow{5}{*}{ ODA } & Neuroticism & 16.45 & 21.78 & 6.70 & $14.00-18.90$ & $4.33^{*}$ & 0.61 & 0.68 \\
\hline & Extraversion & 32.29 & 29.86 & 6.05 & $30.06-34.52$ & $2.19 *$ & 0.30 & 0.34 \\
\hline & Openness & 30.16 & 29.79 & 5.01 & $28.32-32.00$ & 0.40 & 0.05 & 0.06 \\
\hline & Agreeableness & 29.06 & 30.58 & 3.82 & $27.67-30.45$ & $2.15^{*}$ & 0.26 & 0.31 \\
\hline & Conscientiousness & 30.84 & 30.89 & 5.09 & $28.98-32.70$ & 0.05 & 0.01 & 0.01 \\
\hline \multirow{5}{*}{ ED } & Neuroticism & 20.82 & 21.78 & 7.74 & $16.83-24.80$ & 0.45 & 0.11 & 0.12 \\
\hline & Extraversion & 36.41 & 29.86 & 4.11 & $34.29-38.53$ & $6.40 *$ & 0.81 & 1.02 \\
\hline & Openness & 28.53 & 29.79 & 6.14 & $25.37-31.69$ & 0.76 & 0.19 & 0.20 \\
\hline & Agreeableness & 30.41 & 30.58 & 5.26 & $27.72-33.10$ & 0.12 & 0.03 & 0.03 \\
\hline & Conscientiousness & 33.12 & 30.89 & 7.62 & $29.20-37.04$ & 1.17 & 0.28 & 0.29 \\
\hline \multirow{5}{*}{ MDS } & Neuroticism & 21.36 & 21.78 & 4.78 & $18.15-24.57$ & 0.29 & 0.05 & 0.06 \\
\hline & Extraversion & 33.64 & 29.86 & 5.97 & $29.63-37.65$ & 1.57 & 0.47 & 0.53 \\
\hline & Openness & 28.09 & 29.79 & 4.68 & $24.95-31.23$ & 0.82 & 0.25 & 0.29 \\
\hline & Agreeableness & 26.64 & 30.58 & 5.94 & $22.65-30.62$ & $2.22 *$ & 0.67 & 0.67 \\
\hline & Conscientiousness & 31.82 & 30.89 & 6.68 & $27.34-36.30$ & 0.39 & 0.12 & 0.13 \\
\hline
\end{tabular}

*Result is significant at the 0.05 level.

${ }^{x} \mathrm{SD}$ and $95 \% \mathrm{CI}$ for the population are in the sample description above. 


\section{Discussion}

Agreeableness. People who are high in agreeableness highly value the existence of the welfare state and they are against social reforms that have a deep impact on socially weak people (Strauss, Connerley, \& Ammermann, 2003). These issues are conventional parts of left-wing party programs. Members of one of the two left-wing parties - KSČM - were higher in agreeableness than the population sample. This is consistent with findings of the relationship between left-right orientation / political party membership and voting preferences in other countries. However, this finding was not confirmed for the other left-wing party, ČSSD.

The members of two of the three right-wing parties - ODS and ODA - were found to be lower in agreeableness than the population sample. Members of MDS (the regional party) were found lower in agreeableness than the overall Czech population sample as well. According to MDS, the nation of Moravia was struggling for existence against the Czech majority (Hloušek, 2015). The belief that nations fight each other in the "jungle" of the world is the main underlying principal of social dominance orientation (SDO; Duckitt, Wagner, Plessis, \& Birum, 2002). The difference in agreeableness is similar to the negative correlation between SDO and agreeableness (Duckitt \& Sibley, 2016).

Openness. Members of only one of the right-wing political parties - ODS - were found to score lower in openness to experience than the population sample and there was no relationship found between openness and left-wing party membership. This only partially replicates the results concerning the connection between openness and left-wing activism (Blankenship, Frederick, Savas, Stewart, \& Montgomery, 2017) and liberalism (Xu, Plaks, \& Peterson, 2016; Gerber, Huber, Doherty, \& Dowling, 2011), or the negative correlation between openness and the preference for rightist parties from other countries (Caprara et al., 1999; Schoen \& Schumann, 2007). However, this might be because the simplistic left-right or liberalconservative dichotomy might not easily be applied to the Czech political parties: ODA and ED (referred to here as right-wing parties) were parties with many liberal issues included in their political program, and KSČM (referred to here as the left-wing party) is a party which celebrates the old times of the communist regime and rejects the new liberal society. The Greens (SZ, a centrist party) scored higher in openness than the population sample. This corresponds to the results of Schoen and Schumann (1997).

Extraversion. Members of three parties scored high in extraversion: Members of two of the three right-wing parties - ODA and ED - were found to be higher in extraversion than the population sample. Additionally, members of the left-wing ČSSD were found to be higher in extraversion as well. Extraversion was not related to political party membership and political orientation in all of the studies mentioned in the Introduction section, and it seems to not be related to the left-right political orientation in the Czech Republic because members of both left- and right-wing parties scored higher than the population sample. There may be another reason that members of ČSSD (a left-wing party) were higher in extraversion. Politicians were found to be higher than the population in extraversion in Italy (Caprara et al., 2003) and politically active people were found higher in extraversion in Finland (Lindell \& Strandberg, 2018). C SSD was a party that had been in power for seven years in 2005 and the delegates who were elected to represent the strongest party in a regional summit were probably close to professional politicians.

Conscientiousness. ČSSD members scored significantly higher in conscientiousness than the population sample, while there was no significant difference in conscientiousness between other parties' members and the population sample. This result contradicts the findings from 
other countries that conscientiousness suggests a preference for right-wing parties (Caprara et al., 1999; Van Hiel et al., 2004; Schoen \& Schumann, 2007) or a negative relationship between conscientiousness and left-wing political orientation (Xu \& Peterson, 2017).

Neuroticism. Members of KSČM (left-wing) and ODA (right-wing) were lower in neuroticism than the population sample. Respondents from the Communist party (i.e., KSČM) had been members for more than 30 years. They were members of the party when it was in power, as well as after the revolution when it lost power; they continued to be party members even when membership was no longer advantageous. On average, respondents from ODA were members of the party from 1994. ODA lost power in 1998, but they were still members in 2005 when it was not profitable for them anymore. High emotional stability (or low neuroticism) could be the personality trait which differentiates those who leave when a party loses power and those who remain despite the troubled times.

The demographic structure of members differs among parties. The target groups of parties were also different when these parties were established. The reported personality differences between the membership of parties might, therefore, be caused by differences in age and gender structure. Nevertheless, age and gender structure are inseparable parts of party identity and the personality characteristics influenced by this structure are part of the party's "personality". Obviously, the findings for the Czech party members are fairly specific, because - as shown by Fatke (2017) - connections between political ideology and Big Five personality types are different in different cultures.

The current study might be influenced by social desirability. Respondents knew that the data were being collected as research about their political party and the NEO questionnaire contains many items that tend to be socially desirable. Respondents could have had the motivation to respond in a way that the research would show more positive information about their party. This is especially likely for data collected with the help of party members.

\section{Conclusion}

This article presented the personality differences between the general Czech population and the members of major Czech political parties in 2005. Some differences were consistent with the results from other countries. Agreeableness seems to be related to left-wing rather than rightwing party membership, openness is related to membership in the Green party both in the Czech Republic and abroad. Openness and conscientiousness in the Czech case were not related to the left-right preference that had been found in other countries (e.g., Caprara, Barbaranelli, \& Zimbardo, 1999). Nevertheless, results reported in this study are based on samples of party members, which provides a different perspective than the voters' samples reported from other countries.

Research concerning the connections between personality and political preference usually operationalizes political preference as a dichotomy, like liberal-conservative, which is not applicable for a multi-party system. It seems that it is better to discuss the connection between personality and some party membership with regard to the party's history and position in society. Lower neuroticism among members of KSČM and ODA might be related to those parties' long-term absence from the government. The lower agreeableness of MDS members might be related to their feeling of being excluded from mainstream society. The higher conscientiousness of ČSSD could be related to their long-term possession of power. Given the historical and cultural dependence of the politics-personality relationship, it might not be 
possible to replicate the results of this research in other multi-party systems (Fatke, 2017). I recommend that subsequent researchers analyze the situation in their respective societies and focus on the position of a specific party in that society more than on that party's international ideological classification.

It is also questionable whether these results might be generalized over periods. Political programs and the position of political parties within political systems change. Consequently, the reasons people join a specific political party change. People who join such a party today might be different from those who were members 10 years ago. Several parties (i.e., ODA, ED, MDS) whose membership was studied in this research ceased to exist since the data was collected. Personality differences between these party members and the general population are probably unrelated to differences between population and the new parties established in the last decade (or the postulation of such differences based on the presented results would be complete fiction). The psychology that-studies specific human groups (like political parties) is a historical discipline. The results of such investigations might be used as a reference for thinking about current human groups but cannot be directly replicated (because human groups do not replicate across history). These presented results might be useful when thinking about the current Czech political parties (including the current versions of the political parties included in this study), but they are mainly relevant for the time when they were collected. The present research is useful as a psychological investigation of Czech political parties' members in 2005 and it might bring some information to researchers interested in these members' personalities. For those interested in the current political parties, results concerning parties right of the center (i.e., ODA, ODS, ED) and left of the center (i.e., ČSSD, KSČM) might perhaps be useful for the investigation of the current political spectrum.

\section{References}

Aidt, T., \& Rauh, Ch. (2018). The Big Five personality traits and partisanship in England.

Electoral Studies, 54, 1-21. https://doi.org/10.1016/j.electstud.2018.04.017

Blankenship, B.T., Frederick, J.K., Savas, Ö., Stewart, A.J., \& Montgomery, S. (2017). Privilege and marginality: How group identification and personality predict right- and leftwing political activism. Analyses of Social Issues and Public Policy, 17, 161-183. https://doi.org/10.1111/asap.12132

Caprara, G.V., Barbaranelli, C., Zimbardo, P.G. (1999). Personality profiles and political parties. Political Psychology, 20, 175-197. https://doi.org/10.1111/0162-895X.00141

Caprara, G.V., Barbaranelli, C., Consiglio, C., Picconi, L., \& Zimbardo, P.G. (2003). Personalities of politicians and voters: Unique and synergistic relationships. Journal of Personality and Social Psychology, 84, 849-856. https://doi.org/10.1037/00223514.84.4.849

Caprara, G.V., Schwartz, S., Capanna, C., Vecchione, M., \& Barbaranelli, C. (2006). Personality and politics: Values, traits, and political choice. Political Psychology, 27, 1-29. https://doi.org/10.1111/j.1467-9221.2006.00447.x

Cooper, C. A., Golden, L., \& Socha, A. (2013). The Big Five personality factors and mass politics. Journal of Applied Social Psychology, 43, 68-82. https://doi.org/10.1111/j.15591816.2012.00982.X

Cordell, K., \& Hausvater, Z. (2006). Working together: The partnership between the Czech and German Greens as a model for wider Czech-German co-operation. Debatte, 14, 49-69. https://doi.org/10.1080/09651560600643718 
Costa, P.T., \& McCrae, R.R. (1992). Professional manual for the Revised NEO Personality Inventory and the NEO Five-Factor Inventory. Odessa: Psychological Assessment Resources.

Devenport, S.P., \& North, A.C. (2019). Predicting musical taste: Relationships with personality aspects and political orientation. Psychology of Music, 47(6), 834-847. https://doi.org/10.1177/0305735619864647

Duckitt, J., \& Sibley, Ch.G. (2016). Personality, ideological attitudes, and group identity as predictors of political behavior in majority and minority ethnic groups. Political Psychology, 37, 109-124. https://doi.org/10.1111/pops.12222

Duckitt, J., Wagner, C., du Plessis, I., \& Birum, I. (2002). The psychological bases of ideology and prejudice: Testing a dual process model. Journal of Personality and Social Psychology, 83, 75-93. https://doi.org/10.1037/0022-3514.83.1.75

Ekstrom, P.D., \& Federico, Ch.M. (2019). Personality and political preferences over time: Evidence from a multiwave longitudinal study. Journal of Personality, 87, 398-412. https://doi.org/10.1111/jopy.12398

Fatke, M. (2017). Personality traits and political ideology: A first global assessment. Political Psychology, 38, 881-899. https://doi.org/10.1111/pops.12347

Furnham, A., \& Fenton-O'Creavy, M. (2018). Personality and political orientation. Personality and Individual Differences, 129, 88-91. https://doi.org/10.1016/j.paid.2018.03.020

Handl, V. (2005). Choosing between China and Europe? Virtual inspiration and policy transfer in the programmatic development of the Czech Communist Party. Journal of Communist Studies and Transition Politics, 21,123-141. https://doi.org/10.1080/13523270500055561

Hanley, S. (2012). Dynamics of new party formation in the Czech Republic 1996-2010: looking for the origins of a 'political earthquake'. East European Politics, 28(2), 119-143. https://doi.org/10.1080/21599165.2012.669733

Hloušek, V. (2015). From region to nation and back again: Moravian parties' rhetoric and politics in the course of time. Annual of Language and Politics and Politics of Identity, 9(1), 5-22.

Hnilica, K. (2001). Politická orientace, systém hodnot a hodnocení společenských změn [Political orientation, system of values and rating of changes in society]. Československá psychologie, 45, 393-407.

Hřebíčková, M., \& Urbánek, T. (2001). NEO - pětifaktorový osobnostní inventář [NEO-Five Factor Inventory]. Praha: Testcentrum.

Gerber, A. S., Huber, G.A., Doherty, D., \& Dowling, C.M. (2011). The Big Five personality traits in the political arena. Annual Review of Political Science, 14, 265-287. https://doi.org/10.1146/annurev-polisci-051010-111659

Joly, J. K., Hofmans, J., \& Loewen, P. (2018). Personality and party ideology among politicians. A closer look at political elites from Canada and Belgium. Frontiers in Psychology, 9:552. https://doi.org/10.3389/fpsyg.2018.00552.

Lindell, M., \& Strandberg, K. (2018). A Participatory personality? examining the influence of personality traits on political participation. Scandinavian Political Studies, 41, 239-262. https://doi.org/10.1111/1467-9477.12118

Ludeke, S. G., \& Rasmussen, S. H. R. (2016). Personality correlates of sociopolitical attitudes in the Big Five and Eysenckian models. Personality and Individual Differences, 98, 30-36. https://doi.org/10.1016/j.paid.2016.03.079

McCrae, R.R., \& Costa, P.T. (1999). A five-factor theory of personality. In L. A. Pervin \& O. P. John (Eds.), Handbook of Personality. Theory and Research (pp. 139-153). New York: The Guilford Press. 
McFarland, S. G., Ageyev, V. S., \& Abalakina-Paap, M. A. (1992). Authoritarianism in Soviet Union. Journal of Personality and Social Psychology, 63, 1004-1010. https://doi.org/10.1037/0022-3514.63.6.1004

Osborne, D., \& Sibley, C. G. (2012). Does personality matter? Openness correlated with vote choice, but particularly for politically sophisticated voters. Journal of Research in Personality, 46, 743-751. https://doi.org/10.1016/j.jrp.2012.09.001

Schoen, H., \& Schumann, S. (2007). Personality traits, partisan attitudes, and voting behavior. Evidence from Germany. Political Psychology, 28, 471-498. https://doi.org/10.1111/j.1467-9221.2007.00582.x

Strauss, J. P., Connerley, M. L., \& Ammermann, P. A. (2003). The „threat hypothesis“, personality and attitudes toward diversity. The Journal of Applied Behavioral Science, 39, 32-52. https://doi.org/10.1177/0021886303039001002

Van Hiel, A., Mervielde, I., \& De Fruyt, F. (2004). The relationship between maladaptive personality and right-wing ideology. Personality and Individual Differences, 36, 405-417. https://doi.org/10.1016/S0191-8869(03)00105-3

Wang, Ch. H. (2016). Personality traits, political attitudes, and vote choice: Evidence from the United States. Electoral Studies, 44, 26-34. https://doi.org/10.1016/j.electstud.2016.07.004

$\mathrm{Xu}, \mathrm{X} .$, \& Peterson, J.B. (2017). Differences in media preference mediate the link between personality and political orientation. Political Psychology, 38, 55-72. https://doi.org/10.1111/pops.12307

Xu, X., Plaks, J.E., \& Peterson, J.B. (2016). From dispositions to goals to ideology: Toward a synthesis of personality and social psychological approaches to political orientation. Social and Personality Psychology Compass, 10, 267-280. https://doi.org/10.1111/spc3.12248

\begin{abstract}
About the author
Václav Linkov works as a researcher in transportation psychology at Department of Autonomous Driving, CDV - Transport Research Centre. He received master degrees in mathematics and psychology and $\mathrm{PhD}$. in social psychology from Masaryk University. He also spent two years studying doctoral program in Asia-Pacific studies at National Chengchi University. Currently he studies doctoral program at Department of Mathematics, Faculty of Mechanical Engineering, Brno University of Technology. Research presented in this text was his master thesis at Department of Psychology, Faculty of Social Studies, Masaryk University.
\end{abstract}

\title{
Contact details
}

Address: Department of Autonomous Driving, CDV - Transport Research Centre, Líšeňská 33a, 636 00, Brno, Czech Republic;

Department of Psychology, Faculty of Social Studies, Masaryk University, Joštova 10, 602 00, Brno, Czech Republic.

Email: vaclav.linkov@cdv.cz

Linkov, V. (2020). Political party membership and personality characteristics in the Czech Republic (2005). E-psychologie, 14(2), 24-36. https://doi.org/10.29364/epsy.370 